PRODUCTION

ENGINEERING ARCHIVES
2014, Vol. 4, No. 3, pp 11-13

ISSN 2353-5156 (print version)

ISSN (online version)
Article history: $\quad$ Received: 27.05.2014

Available online on: http://www.qpij.pl
Accepted: 10.06.2014

Online: 01.10.2014

Exist since $4^{\text {rd }}$ quarter 2013

\title{
Quality analysis of plates for car industry
}

\author{
Pawel Szklarzyk $^{1}$, Dorota Klimecka-Tatar ${ }^{2}$, Piotr Sygut $^{3}$, Tomasz Lipińki ${ }^{4}$ \\ ${ }^{1,2,3}$ University of Technology. Faculty of Management. Management and Engineering of Production. Poland. \\ ${ }^{4}$ University of Warmia and Mazury in Olsztyn
}

\begin{abstract}
In 2013, global steel production reached a level of 1.548 million tons. This value indicates that, in the $21^{\text {st }}$ century, steel is still one of the most popular construction materials. In Poland 8.2 million tons of steel was produced in 2013. A large share of steel is used for the production of hot-rolled plates for car bodies. Steel products made in high temperature processes are used in virtually all sectors of industries. The hot-rolled plates for car bodies should comply with the highest quality requirements. In this chapter the results of research from the 3-month follow-up are presented. To assess the level of non-conformity in hot-rolled plates the Pareto-Lorenz diagram was used. The results are the basis for the improvement of the production process of hot-rolled products.
\end{abstract}

Key words - hot-rolled products, Pareto-Lorenz diagram, steel company, TQM

\section{Introduction}

Quality is a concept with a philosophical grounding. Plato said: 'quality - (gr. poiotes, łac. qualitas) is a certain level of perfection'. According to the standard PN-EN ISO 2000:2006, quality is defined as: 'the degree to which a set of inherent characteristics fulfils requirements'. The quality level of hot-rolled products depends on: wrong thickness, mechanical damage, shell.

Polish Standard PN-EN ISO 9000:2006 defines nonconformities as non-fulfilment of a requirement (PN-EN ISO 9000:2006).

For car companies the quality of products is crucial because it is one of the main factors influencing the degree of customer satisfaction. To meet the expectations of customers car companies should look for new methods of improving quality. In order to apply appropriate improvement tools, it is necessary to iden- tify non-conformities that affect the quality of the product.

\section{Experiment}

The assessment of the quality of the hot-rolled plates was carried out in a hot mill in Poland. The observation period was one calendar year. During the 3month study period, data was collected on any emerging non-conformities and their quantitative presence. Research was carried out for one grade of steel. The steel used for production of the plates belongs to a group of structural steels for cold forming. The investigation was carried out on S260NC steel. Chemical composition of the steel investigated is given in Table 1 (PN-EN 10149-3:2000, DOBRZAŃSKI L. 2012). 
Table 1. Chemical composition of steel S260NC [\%]

\begin{tabular}{|c|c|c|c|c|}
\hline $\begin{array}{c}\text { STEEL } \\
\text { GRADE }\end{array}$ & $\mathbf{C}$ & $\mathbf{M n}$ & $\mathbf{S i}$ & $\mathbf{P}$ \\
\hline \multirow{3}{*}{ S260NC } & 0.16 & 1.2 & 0.5 & 0.025 \\
\cline { 2 - 5 } & $\mathrm{S}$ & $\mathrm{Nb}$ & $\mathrm{V}$ & $\mathrm{Ti}$ \\
\cline { 2 - 5 } & 0.02 & 0.09 & 0.1 & 0.15 \\
\hline
\end{tabular}

\section{Analysis of non-conformities during the hot-rolled plates production process}

For the assessment of non-conformities in hotrolled plates the Pareto-Lorenz diagram was used.

Pareto-Lorenz diagram is one of the seven basic tools of quality management. It is based on an established empirical regularity that in nature, technology and human activity, usually $20 \div 30 \%$ of the causes decided by about $70 \div 80 \%$ impact (BORKOWSKI S. 2004). Pareto - Lorenz can be used to present all phenomena and relationships that can be presented numerically and make a percentage. It sets out to give validity to factors causing the problem (BORKOWSKI S. 2004, BORKOWSKI S., UlEWICZ R. 2003, UlEWICZ R. 2009).

The non-conformities discovered during the research are presented in the Table 2.

Table 2. Types of nonconformities detected during of the hot-rolled plates production process

\begin{tabular}{|c|c|}
\hline $\begin{array}{c}\text { Symbol of non- } \\
\text { conformities }\end{array}$ & Names of nonconformities \\
\hline N1 & Interruption of metal \\
\hline N2 & Other \\
\hline N3 & Bad thickness \\
\hline N4 & Pinchers \\
\hline N5 & Honeycomb blowholes \\
\hline N6 & Irregular dimensions \\
\hline N7 & Mechanical damages \\
\hline N8 & Overlap \\
\hline N9 & Shells \\
\hline N10 & Cockles (two sides) \\
\hline N11 & Cockles (one sides) \\
\hline N12 & Alligatoring \\
\hline
\end{tabular}

Table 3 shows the percentage share of nonconformities occurring during hot-rolled plate production processes in the first quarter of the year.
The data presented in Table 3 contains information about mass non-conforming plates $(\mathrm{Mg})$, and the percentages of each non-conforming plates.

Based on data from Table 3 the Pareto-Lorenz diagram was constructed (Fig. 1).

It was found that in the first quarter year 7794.07 $\mathrm{Mg}$ of nonconforming products were produced.

Table 3. Percentage share of non-conformities occurring during the production of hot-rolled plates in the first quarter of the year

\begin{tabular}{|c|c|c|}
\hline \multicolumn{3}{|c|}{ I QUARTER YEAR } \\
\hline $\begin{array}{c}\text { Symbol of non- } \\
\text { conformities }\end{array}$ & $\begin{array}{c}\text { Amount } \\
{[\mathbf{M g}]}\end{array}$ & $\begin{array}{c}\text { The per- } \\
\text { centage } \\
\text { share } \\
{[\mathbf{\%}]}\end{array}$ \\
\hline $\mathbf{N}_{\mathbf{1}}$ & 1714.9 & 22.00 \\
\hline $\mathbf{N}_{\mathbf{3}}$ & 1456.7 & 18.69 \\
\hline $\mathbf{N}_{\mathbf{1 0}}$ & 1292.3 & 16.58 \\
\hline $\mathbf{N}_{\mathbf{2}}$ & 1181 & 15.15 \\
\hline $\mathbf{N}_{\mathbf{9}}$ & 914.7 & 11.74 \\
\hline $\mathbf{N}_{\mathbf{1 1}}$ & 579.9 & 7.44 \\
\hline $\mathbf{N}_{\mathbf{7}}$ & 240.7 & 3.09 \\
\hline $\mathbf{N}_{\mathbf{8}}$ & 180.7 & 2.32 \\
\hline $\mathbf{N}_{\mathbf{6}}$ & 146.7 & 1.88 \\
\hline $\mathbf{N}_{\mathbf{4}}$ & 73 & 0.94 \\
\hline $\mathbf{N}_{\mathbf{5}}$ & 11.1 & 0.14 \\
\hline $\mathbf{N}_{\mathbf{1 2}}$ & 2.36 & 0.03 \\
\hline & 7794.07 & 100 \\
\hline
\end{tabular}

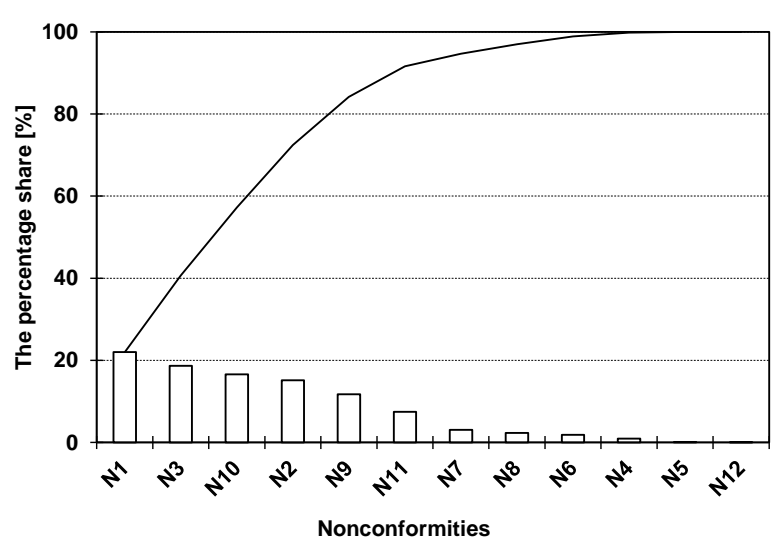

Fig. 1. The Pareto-Lorenz diagram for the nonconformities occurring during the production of hot-rolled plates $1^{\text {st }}$ quarter of the year.

Source: own study 
Based on the Table 3 and Figure 1, it could be stated that for over $57.27 \%$ of all detected nonconformities only $25 \%$ types of non-conformities were found.

$57.27 \%$ of defects are connected with only three problems: interruption of metal, insufficient thickness and cockles (two sides) whereas the remaining types of defects are merely $42.73 \%$ in total of all defects.

Based on the test of results obtained, it was found that the most common causes that affect the nonconforming products are:

- Cockles (two sides) - srelated to a non-uniform deformation of the metal along the width during rolling. Local deformation causes a local elongation of the sheet. Wave is caused by excessive deflection rollers or badly matched by rolling method.

- Interruption of metal is due to poorly prepared ingot causing decrease in strength of sheet and its mechanical properties.

- Insufficient thickness is associated with bad calibration rollers.

\section{Summary}

This chapter presents the results of research carried out in the mill plates. The aim of the study was to determine the level of quality of hot-rolled plates for car bodies.

The global market requires manufacturers to deliver the highest quality products. Quality is a determinant of customer satisfaction. Steelworks in Poland produce about 8 million tons of steel per year of which $90 \%$ is used for the production of hot-rolled products.

The results obtained illustrate the main causes of non-conforming products. The rolling mill has significant problems with the quality of the product. The total mass of non-conforming products amounted to 7794 tons. The analysis of 10 studies detected nonconformities. The greatest losses generate three problems: Interruption of metal, cockles (two sides) and bad thickness.

\section{References}

1. PN-EN ISO 2000:2006. Systemy zarządzania jakościa. Podstawy i terminologia.

2. PN-EN 10149-3:2000.

3. BoRKOWSKI S.2004. Mierzenie poziomu jakości. Publisher Wyższa Szkoła Zarządzania i Marketingu in Sosnowiec. Sosnowiec.

4. BoRKOWSKI S., UlEWICZ R. 2009. Instrumenty doskonalenia procesów produkcyjnych. Wyd. PTM. Warszawa.

5. DobrZAŃski L. A. 2002. Podstawy nauki o materiałach $i$ metaloznawstwo. Materiaty inżynierskie z podstawami projektowania materiałowego. Wydawnictwo NaukowoTechniczne. Gliwice-Warszawa.

6. ULEWICZ R. 2003. Quality control system in production of the castings from spheroid cast iron. In: Metalurgija, Croatia. Vol. 42, Issue 1, pp. 61-63.

7. Krynke M., MielczareK K. 2013. An evaluation of realization of the production process in the cement mill. Prodution Engineering Archives. No. 1. ISSN 23535156. 